\title{
Kepemimpinan Transformasional dan Efikasi Kolektif Karyawan Selama Pandemi Covid-19
}

\author{
Danella Victoria Putri Hastika ${ }^{1}$, Diana Savitri Hidayati², Nandy Agustin Syakarofath ${ }^{3}$
}

Fakultas Psikologi, Universitas Muhammadiyah Malang

Jl. Raya Tlogomas No. 246

danellahastika99@gmail.com,nandysyakarofath@umm.ac.id

\begin{abstract}
Abstrak
Kebijakan work from home (WFH) selama pandemi Covid-19 di Indonesia membawa dampak perubahan diberbagai bidang khususnya di dunia industri dimana banyak pekerjaan yang melibatkan kerjasama tim. Keberhasilan kerjasama tim dalam menyelesaikan tugas dan pekerjaan membutuhkan efikasi kolektif, yaitu sebuah keyakinan bersama sebuah tim untuk dapat menuntaskan dengan baik terkait pekerjaan yang sedang ditangani. Menurut berbagai studi salah satu faktor penentu kuatnya efikasi kolektif disebabkan oleh kepemimpinan transformasional, yaitu kemampuan pemimpin di dalam memberdayakan anggotanya dengan optimal. Tujuan penelitian ini berusaha mengungkap bagaimana peran kepemimpinan transformasional terhadap efikasi kolektif karyawan selama WFH. Subjek penelitian ini adalah 152 karyawan yang bekerja di perusahaan milik negara (BUMN) dan perusahaan milik swasta (BUMS) di daerah Jawa Timur yang diperoleh menggunakan teknik random sampling. Instrumen yang digunakan adalah skala kepemimpinan transformasional dan skala efikasi kolektif. Berdasarkan uji regresi linier sederhana didapatkan data bahwa ada peran kepemimpinan transformasional terhadap efikasi kolektif karyawan selama WFH $(\mathrm{R}=0.350, \mathrm{P}=0,000<0,005)$. Artinya kepemimpinan transformasional mampu memprediski efikasi kolektif karyawan dalam menuntaskan pekerjaan yang ditangani. Kontribusi sumbangan efektif kepemimpinan transformasional terhadap efikasi kolektif karyawan dalam penelitian ini sebesar $12,3 \%$
\end{abstract}

Kata kunci: efikasi kolektif, kepemimpinan transformasional, work from home

\begin{abstract}
The work-from-home (WFH) policy implemented in Indonesia during the COVID-19 pandemic has caused changes in a variety of fields, particularly in the industrial world, where much of the work requires teamwork. Successful teamwork in completing tasks and work requires collective efficacy, which is a belief among members of a team that they will be able to complete well related to the work at hand. According to various studies, transformational leadership is one of the determinants of the strength of collective efficacy, namely the ability of leaders to optimally empower their members. The goal of this research is to discover how transformational leadership roles affect employee collective efficacy during WFH. The subjects of this study were 152 employees from state-owned enterprises (SOEs) and privately owned enterprises (BUMS) in East Java who were chosen at random. The transformational leadership scale and the collective efficacy scale were used as tools. Data from a simple linear regression test revealed that transformational leadership plays a role in employee collective efficacy during WFH $(\mathrm{R}=0.350, \mathrm{P}=0,0000.005)$. This means that transformational leadership can discuss the collective efficacy of employees in completing the work at hand. In the study, effective transformational leadership contributed 12.3 percent to employee collective efficacy.
\end{abstract}

Keywords: collective efficacy, transformational leadership, work from home

\section{PENDAHULUAN}

Karyawan merupakan salah satu unsur utama dalam sebuah perusahaan. Tidak adanya karyawan, akan membuat proses aktivitas dalam sebuah perusahaan menjadi tidak terlaksana. Persaingan kualitas sumber daya manusia dalam sebuah perusahaan semakin penting pada 
masa-masa ini. Serangan virus Covid-19 yang melanda seluruh dunia, membuat banyak perubahan terjadi di berbagai negara baik dalam segi perekonomian, pendidikan, maupun dalam hal budaya kerja. Aturan baru sudah dibentuk untuk mengurangi peningkatan jumlah positif Covid-19, salah satunya adalah Work From Home (WFH) atau lebih dikenal dengan bekerja dari rumah. Para karyawan diminta untuk menyelesaikan tugas yang biasanya mereka kerjakan di kantor bersama-sama dengan membawanya dan menyelesaikannya di rumah. Mustajab (2020) menyatakan bahwa 10 tahun terakhir konsep WFH sudah menjadi bahan diskusi dan juga tema studi global bagi para peneliti.

Bekerja dari rumah (work form home) merupakan kebijakan kerja di dunia Industri saat pandemi covid-19 melanda dan menimbulkan berbagai dampak. Dua dan Mea (2020) menyebutkan WFH memiliki dampak negatif yaitu kehidupan antara dunia kerja dan pribadi menjadi tidak seimbangkan karena tidak adanya batasan waktu yang jelas untuk menjalankan peran keduanya. Ketidak seimbangan didunia kerja terjadi karena sulitnya menjalankan kerjasama tim saat interaksi terbatas di dunia maya dibandingkan dengan interaksi langsung saat non WFH (Setyawan, 2020). Sulitnya menjalankan kerjasama tim saat WFH membuat ketegangan antar anggota kelompok, berbagai perasaan negatif dan konflik (Mungkasa 2020). Lebih lanjut, dampak lain yang ditimbulkan adalah performa kinerja karyawan menurun, khususnya yang melibatkan aktivitas kelompok (Lippe, 2019).

Munculnya berbagai ketegangan atau konflik antar kelompok saat WFH disebabkan karena antar individu atau anggota kelompok terkait tidak memiliki keyakinan berasama (efikasi kolektif) bahwa kerja sama tim dapat berjalan dengan baik. Keyakinan bersama atau efikasi kolektif tersebut menurut Joe dan Lin, (2008) sangat terkait dengan adanya masalah antar anggota dalam menentukan tujuan bersama, kepuasan kerja, kesejahteraan psikologis antar anggota dan perilaku kewarganegaraan organisasi/organizational citizenship behavior (OCB) (Joe \& Lin, 2008). Lebih lanjut, bahwa keyakinan bersama (efikasi kolektif) tersebut mampu mempredikasi performansi dan kinerja tim (Azizah; 2017), dan kualitas hubungan antar anggota tim dan kepuasan individu (Jowett, Shanmugam, \& Caccoulis, 2012), serta kepuasan kerja (Klassen et al, 2010). Artinya apabila ada persoalan terkait efikasi kolektif maka peluang dampak negatif yang mampu mengancam harmonisasi jalannya organisasi semakin besar.

Bandura (1997) mendefiniskan efikasi kolektif sebagai suatu keyakinan yang dimiliki oleh kelompok terkait mampu bersama-sama mengatur dan melaksanakan setiap tindakan untuk kepentingan bersama dan tercapainya tujuan bersama. Mendukung pernyataan Bandura, Jung (2002) menyebutkan bahwa efikasi kolektif menjadi konstruksi penting dalam pembentukan dan keberlangsungan sebuah kelompok sehingga penting menjadi perhatian di dunia kerja yang setiap aktivitasnya berkaitan erat dengan tugas bersama (sebuah kelompok). Hal ini diperkuat oleh pendapat Çepikkurt dan Uluöz (2017) bahwa tanpa adanya efikasi kolektif dan kohesi kelompok suatu pekerjaan yang melibatkan kelompok tidak akan berjalan efektif.

Faktor penentu efikasi kolektif bervariasi. Menurut berbagai studi, faktor eksternal memiliki peran yang paling besar dampaknya terhadap pembentukan efikasi kelompok tersebut khususnya peran dari pimpinan. Menurut Çalik, et al., (2012), jenis kepemimpinan yang mampu memprediksi efiksi kelompok karyawan adalah kempimpinan instruksional, yaitu sebuah kepimpinan yang dicikan dengan dominansi atasan untuk memberikan intruksi yang jelas dan berkualitas terhadap karyawannya sebagai daya penggerak jalannya organisasi. Berbeda dengan pendapat tersebut, Yuwono, et al., (2020) justru menyebutkan bahwa penentu dari efikasi kelompok adalah kepemimpinan transformasional, yaitu kepemimpinan yang dicirikan dengan pemberdayaan karyawan melalui transformasi kewenangan dari pimpinan untuk menjalan tugas dan pekerjaan sehingga karyawan turut berkembang meskipun penuh resiko dan tantangan didalam menjalankannya. Dengan demikian, dapat dipahami bahwa sejatinya 
kepemimpinan merupakan aspek kritis yang perlu mendapatkan perhatian khusus karena akan mempengaruhi bagaimana performansi karyawannya.

Banyaknya jenis kepimpinan yang ada, peneliti memfokuskan kepemimpinan transformasional yang akan diuji lebih lanjut untuk dibuktikan efektivitasnya terhadap efikasi kolektif karyawan. Hal ini disebabkan kuatnya bukti penelitian terdahulu yang menunjukkan hubungan yang signifikan antar keduanya. Wahyu, Widodo, dan Kurniawan (2020) dengan kepemimpinan transformasional karyawan dapat menjadi lebih termotivasi dan tenang dalam mengahadapi berbagai situasi yag tidak pasti. Mendukung pernyataan tersebut Gita (2016) menyatakan bahwa karyawan menjadi terinspirasi untuk dapat lebih optimal berkontribusi, dan berkomitmen terhadap tujuan bersama yaitu organisasi.

Pentingnya kepemimpinan transformasional terhadap peningkatan efikasi kolektif karyawan perlu diuji lebih lanjut agar dapat terbukti secara ilmiah efektivitasnya mengingat dampak jangka panjang bagi stabilitas dan keberlangsungan organisasi. Oleh karenanya, hipotesis yang diajukan dalam penelitian ini adalah adanya peran kepemimpinan transformasional dan efikasi kolektif karyawan. Penelitian ini dilakukan untuk mengetahui peran kepemimpinan transformasional terhadap efikasi kolektif. Manfaat penelitian ini adalah untuk menjadikannya sumber informasi dan menambah kajian teoritis terkhusus untuk psikologi dalam bidang industri dan organisasi. Manfaat praktis dalam penelitian ini adalah untuk menambah wawasan dan informasi bagi peneliti dan juga pembaca tentang pengaruh kepemimpinan transformasional terhadap efikasi kolektif pada karyawan yang bekerja WFH, sehingga penelitian ini juga dapat menjadi masukan bagi para pemimpin dalam sebuah perusahaan untuk dapat meningkatkan kualitas para karyawan dengan memberikan dorongan, motivasi, dan menumbuhkan keyakinan pada diri mereka sehingga nantinya dapat mencapai tujuan kelompok bersama.

\section{METODE}

Subjek yang terlibat dalam penelitian ini sejumlah 152 karyawan Badan Usaha Milik Negara (BUMN) dan Badan Usaha Milik Swasta (BUMS) yang berkerja WFH selama pandemi di Jawa Timur. Teknik sampling yang digunakan adalah random sampling menggunakan situs random.org. Randomisasi dilakukan dengan mendata terlebih dahulu kawasan industri di Jawa Timur yang secara umum terbagi menjadi lima 5 wilayah yaitu Surabaya, Gresik, Tuban, Mojokerto dan Pasuruan, Malang. Dari kelima wilayah besar tersebut dilakukan proses randomisasi untuk menentukan 3 wilayah penelitian menggunakan bantuan situs random.org dan terpilih Kabupaten dan Kota Malang, Kabupaten dan Kota Mojokerto serta Kabupaten Sidoarjo.

Terdapat dua instrumen yang digunakan dalam penelitian ini. Instrumen yang pertama adalah skala kepemimpinan transformasional yang terdiri dari lima aspek yaitu idealized influence attributes (IIA), idealized influence behaviour (IIB), inspirational motivation (IM), intellectual stimulation (IS), dan individualized consideration (IC) (Hemsworth, Muterera, \& Baregheh, 2013). Keseluruhan total item yang dimilki sejumlah 20 item dengan indeks reliabilitas sebesar 0.94. Agar dapat digunakan kepada subjek penelitian, skala tersebut diterjemahkan kedalam bahasa Indonesia. Contoh item dari skala kepemimpinan transformasional adalah: Pemimpin saya dapat menanamkan rasa bangga pada bawahannya ..., Pemimpin saya mengutamakan kepentingan kelompok demi kebaikan tim.., dan Pemimpin saya mengutamakan kepentingan kelompok demi kebaikan tim. Intrumen yang kedua adalah skala efikasi kolektif yang terdiri dari lima aspek yaitu persistence, preparation, unity, ability, dan effort (Martínez, Guillén, \& Feltz, 2011). Keseluruhan total item yang dimiliki sejumlah 20 item dengan indeks reliabilitas sebesar 0.63. Agar dapat digunakan kepada subjek penelitian, 
skala tersebut diterjemahkan kedalam bahasa Indonesia. Contoh item dari skala efikasi kolektif adalah: Saya mampu bekerja dibawah tekanan ... Saya mampu bertahan saat dihadapkan dengan suatu permasalahan .... Saya tetap bekerja dengan baik walaupun banyak hambatan yang ditemui. Kedua skala berbentuk likert dan memiliki empat pilihan jawab singkat dalam pengisiannya yaitu sangat sesuai (SS), sesuai (S), tidak sesuai (TS), sangat tidak sesuai (STS).

Pegambilan data dilakukan sejak 22 Maret 2021 hingga 4 Mei 2021 yang dilakukan dengan menyebarkan skala secara online menggunakan google form yang disebarkan melaui berbagai media sosial seperti whatsapp, facebook, instragram dan twitter. Analisis data yang dilakukan menggunakan uji regresi linear sederhana. Sebelum dilakukan uji analisis regresi linear sederhana, terlebih dahulu peneliti uji asumsi sebagai pra syarat yaitu uji normalitas dan multikolinearitas.

\section{HASIL}

Perolehan data yang dilakukan pada 152 karyawan yang tersebar di tiga area Jawa Timur dapat dilihat pada data deskrpsi subjek penelitian sebagai berikut:

Tabel 1.

Deskripsi Subjek Penelitian

\begin{tabular}{|c|c|c|c|c|c|c|c|c|c|c|}
\hline & \multicolumn{5}{|c|}{ Kepemimpinan transformasional } & \multicolumn{5}{|c|}{ Efikasi Kolektif } \\
\hline & \multicolumn{2}{|c|}{ Sedang } & \multicolumn{2}{|c|}{ Tinggi } & \multirow[t]{2}{*}{ Total } & \multicolumn{2}{|c|}{ Sedang } & \multicolumn{2}{|c|}{ Tinggi } & \multirow[t]{2}{*}{ Total } \\
\hline & $\mathrm{F}$ & $\%$ & $\mathrm{~F}$ & $\%$ & & $\mathrm{~F}$ & $\%$ & $\mathrm{~F}$ & $\%$ & \\
\hline \multicolumn{11}{|l|}{ Jenis kelamin } \\
\hline Laki-laki & 14 & $9.2 \%$ & 79 & $52 \%$ & \multirow{2}{*}{$100 \%$} & 3 & $1.9 \%$ & 90 & $59.2 \%$ & \multirow{2}{*}{$100 \%$} \\
\hline Perempuan & 13 & $8.6 \%$ & 46 & $30.2 \%$ & & 2 & $1.3 \%$ & 57 & $37.5 \%$ & \\
\hline \multicolumn{11}{|l|}{ Lama bekerja } \\
\hline$<2$ tahun & 22 & $14.4 \%$ & 99 & $65.1 \%$ & \multirow{2}{*}{$100 \%$} & 4 & $2.6 \%$ & 117 & $76.9 \%$ & \multirow[t]{2}{*}{$100 \%$} \\
\hline$>2$ tahun & 5 & $3.2 \%$ & 26 & $17.3 \%$ & & 1 & $0.6 \%$ & 30 & $19.7 \%$ & \\
\hline \multicolumn{11}{|l|}{ Pendidikan terakhir } \\
\hline SMA-SMA sederajat & 4 & $2.6 \%$ & 13 & $8.5 \%$ & \multirow{4}{*}{$100 \%$} & 1 & $0.6 \%$ & 16 & $10.5 \%$ & \multirow{4}{*}{$100 \%$} \\
\hline D1-D4 & 6 & $3.9 \%$ & 20 & $13.1 \%$ & & 2 & $1.3 \%$ & 24 & $15.7 \%$ & \\
\hline $\mathrm{S} 1$ & 15 & $9.8 \%$ & 77 & $50.6 \%$ & & 3 & $1.9 \%$ & 90 & $59.2 \%$ & \\
\hline $\mathrm{S} 2$ & 2 & $1.3 \%$ & 15 & $9.8 \%$ & & 0 & - & 17 & $11.1 \%$ & \\
\hline \multicolumn{11}{|l|}{ Daerah } \\
\hline Malang & 15 & $9.9 \%$ & 67 & $44 \%$ & \multirow{3}{*}{$100 \%$} & 4 & $2.6 \%$ & 78 & $51.3 \%$ & \multirow{3}{*}{$100 \%$} \\
\hline Mojokerto & 5 & $3.2 \%$ & 29 & $19 \%$ & & 0 & - & 34 & $22.3 \%$ & \\
\hline Sidoarjo & 7 & $4.9 \%$ & 29 & $19 \%$ & & 1 & $0.6 \%$ & 35 & $23 \%$ & \\
\hline \multicolumn{11}{|l|}{ Jenis perusahaan } \\
\hline BUMN & 5 & $3.2 \%$ & 60 & $39.4 \%$ & \multirow[t]{2}{*}{$100 \%$} & 3 & $1.9 \%$ & 62 & $40.7 \%$ & \multirow[t]{2}{*}{$100 \%$} \\
\hline BUMS & 22 & $14.4 \%$ & 65 & $42.7 \%$ & & 2 & $1.3 \%$ & 85 & $55.9 \%$ & \\
\hline
\end{tabular}

Tabel 1 memaparkan bahwa berdasarkan jenis kelamin, lama bekerja, tingkat pendidikan terakhir, asal daerah dan jenis perusahaan mayoritas subjek memiliki taraf kepemimpinan transformasional yang tinggi, begitu juga dengan efikasi kelompoknya. Pada kategori jenis kelamin dimana laki-laki lebih mendominasi dengan persentase 61,2\% (93 subjek) sedangkan perempuan 38,8\% (59 subjek). Kemudian, pada kategorisasi lama bekerja dapat dilihat bahwa karyawan yang bekerja selama 1 tahun berada pada urutan pertama dengan persentase $50,0 \%$ (76 subjek), karyawan yang bekerja selama 2 tahun sebanyak 29,6\% (45 subjek), sedangkan karyawan yang bekerja $>2$ tahun berada pada urutan terakhir dengan persentase 20,4\% (31 subjek). Dilihat dari segi pendidikan, karyawan yang memiliki latar belakang pendidikan terakhir S1 memiliki skor tertinggi dengan persentase 60,5\% (92 subjek), riwayat pendidikan D1-D4 sebanyak 17,1\% (26 subjek), serta riwayat pendidikan SMA/SMK dan S2 memiliki persentase yang sama yaitu sebanyak 11,2\% (17 subjek). Dilihat dari penyebaran daerah, 
karyawan yang bekerja di Kabupaten/Kota Malang lebih mendominasi dengan persentase 53,9\% (82 subjek), daerah Kabupaten Sidoarjo sebanyak 23,7\% (36 subjek), dan karyawan yang bekerja di Kabupaten/Kota Mojokerto berada pada urutan terakhir dengan persentase 22,4\% (34 subjek). Dilihat dari jenis perusahaan, subjek yang bekerja di Badan Usaha Milik Swasta (BUMS) memiliki persentase lebih tinggi yaitu sebanyak 57,2\% (87 subjek), sedangkan karyawan yang bekerja di Badan Usaha Milik Negara (BUMN) sebanyak 42,8\% (65 subjek). Kemudian karyawan yang sedang melakukan Work From Home (WFH) berada pada urutan pertama dengan persentase 59,2\% (90 subjek), sedangkan karyawan yang bekerja Shift/Berjadwal Work From Office (WFO) sebanyak 40,8\% (62 subjek).

Tabel 2.

Uji Regresi Linier Sederhana

\begin{tabular}{lccc}
\hline \multicolumn{1}{c}{ Variabel } & $\begin{array}{c}\text { Koefisien } \\
\text { Regresi }(\mathbf{B})\end{array}$ & $\begin{array}{c}\text { Koefisien } \\
\text { Determinan }\left(\mathbf{r}^{\mathbf{2}}\right)\end{array}$ & $\begin{array}{c}\text { Signifikasi } \\
(\mathbf{p})\end{array}$ \\
\hline $\begin{array}{l}\text { Kepemimpinan transformasional } \\
\text { terhadap efikasi kolektif }\end{array}$ & 0,303 & 0,123 & 0,000 \\
\hline
\end{tabular}

Hasil uji analisis regresi linier sederhana memaparkan data bahwa taraf signifikansi $\mathrm{p}<0.000$, dengan koefisien determinasi (R2) sebesar 0,123. Artinya kepemimpinan transformasional memiliki peran terhadap efikasi kolektif karyawan selama WFH dimasa pandemi. Adapun sumbangan efektif kepemimpinan transformasional terhadap efikasi kolektif karyawan sebesar 12,3\%. Nilai koefisien regresi (B) sebesar 0,303 menunjukkan bahwa setiap penambahan $1 \%$ nilai kepemimpinan transformasional maka nilai efikasi kolektif bertambah sebesar 0,303. Arah peran variabel kepemimpinan transformasional terhadap efikasi kolektif adalah positif.

\section{DISKUSI}

Berdasarkan hasil penelitian yang sudah dilakukan kepada 152 subjek yang terbagi dalam 3 daerah di Jawa Timur, yaitu Kabupaten/Kota Malang sebanyak 53,9\% (82 subjek), Kabupaten Sidoarjo 23,7\% (36 subjek), dan Kabupaten/Kota Mojokerto 22,4\% (34 subjek) didapatkan hasil nilai kepemimpinan transformasional (koefisien regresi/B) sebesar 0,303 yang dimana dapat diartikan bahwa setiap penambahan $1 \%$ nilai gaya kepemimpinan transformasional maka nilai efikasi kolektif bertambah sebesar 0,303. Selain itu, dilihat berdasarkan nilai signifikansi didapatkan hasil bahwa kepemimpinan transformasional berpengaruh positif terhadap efikasi kolektif $(0,000<0,05)$ dengan kontribusi sebesar $12,3 \%$. Dari penjelasan tersebut dapat dikatakan bahwa hipotesis dalam penelitian ini diterima. Semakin tinggi penilaian kepemimpinan transformasional dalam sebuah kelompok maka efikasi kolektif kelompok juga akan semakin tinggi.

Temuan adanya peran dari kepemimpinan transformasional terhadap efikasi kolektif sejalan dengan berbagai hasil penelitian terdahulu. Semakin tinggi derajat kepemimpinan transformasional, maka berdampak semakin tinggi pula efikasasi kolektif kelompok karyawan (Demir, 2008; Zhang, Tsui, \& Wang, 2011). Bukti efektivitas dari kepemimpinan transformational terhadap efikasi kelompok dapat terjadi diberbagai situasi, terurama saat pandemi yang membatasi interaksi sosial meskipun pada beberapa pekerjaan tertentu harus diselesaikan dengan kelompok (Asbari et al 2020). Dalam prosesnya, kepemimpinan transformasional memberikan pengaruh yang positif terhadap karyawan karena mampu memperhatikan dan memperlakukan karyawan dengan lebih baik sehingga sang pemimpin terlihat berkarisma, menginspirasi dan dijadikan sebagai contoh panutan oleh karyawan (Smith, 
Montagno \& Kuzmenko, 2004). Paparan hubungan positif antara kedua variabel yang diteliti terbukti (Pratama, 2018).

Secara umum, skor efikasi kolektif pada karyawan diteliti rerata berdistribusi tinggi yang artinya secara bersama-sama karyawan memiliki keyakinan bahwa terlepas dari situasi pandemi pekerjaan akan terselesaikan dengan baik sebagaimana mestinya. Secara umum Martínez (2011) menyebutkan ada lima ciri karyawan memiliki efikasi kolektif yang baik yaitu memiliki kemampuan dan yakin atas kemampuannya (ability), tekun (persistence), mampu melakukan perencanaan dan persiapan (preparatio), memiliki rasa satu kesatuan (unity)dan diimbangi dengan usaha yang optimal (effort). Tingginya skor efikasi kolektif pada karyawan dipenelitian ini juga di imbangi dengan skor penulaian kepemimpinan transformasional yang juga tinggi pada pimpinannya. Hal ini senada dengan pendapat Pratama (2018) terdapat hubungan yang positif antara penilaian kepemimpinan transformasional terhadap pimpinannya dengan efikasi kolektif bersama karyawan.

Ketika situasi pandemi dan pemberlakukan WFH, peran dari kepemimpinan transformasional terhadap performansi karyawan nyata dirasakan. Situasi pandemi yang menyebabkan terbatasnya gerak dan interaksi membuat karyawan menjadi demotivasi dan produktivitas menurun (Anisah \& Wisesa, 2018). Agar kembali menjadi termotivasi dan produktif maka diperlukan contoh dari atasan yang mampu menggerakkan dan membuat karyawan terinspirasi. Hal ini dapat diperoleh dengan adanya penerapan kepemimpinan transformasional yang dipersespsikan secara positif oleh karyawan dan membuat kinerjanya semakin optimal (Tucunan et al 2014). Pemimpin yang memiliki kepemimpinan transformasional, disituasi pandemi mampu membuat karyawan menjadi lebih tenang dan siap menghadapi situasi apapun (idealized influence), saling terbuka antar rekan kerja (inspirational motivation), serta mampu mengatasi setiap permasalahan dan kebutuhan dari para karyawan (individual stimulation).

Berdasarkan penjelasan diatas, dapat dilihat bahwa pentingnya pemimpin dengan karakter transformasional di masa pandemi Covid-19 ini, yaitu pemimpin yang mampu mentransformasikan segala sumber daya organisasi secara optimal sehingga roda gerak organisasi tetap berjalan. Penerapan gaya kepemimpinan transformasional diharapkan mampu untuk memberikan motivasi dan juga dukungan kepada para karyawannya yang sedang melakukan WFH maupun bekerja secara shift/berjadwal WFO.

Kelemahan dalam penelitian ini adalah hanya memberikan dua pilihan jenis perusahaan saja yaitu BUMN dan BUMS, yang dimana seharusnya dapat memberikan pilihan-pilihan jenis perusahaan yang lebih luas sehingga hasil penelitian ini dapat digeneralisasikan lebih lagi. Adapun kelebihan dalam penelitian ini adalah masih sedikit penelitian yang mengangkat tema efikasi kolektif terhadap para karyawan terlebih di masa pandemi saat ini yang sebagian besar perusahaan sedang menerapkan WFH bagi para karyawannya sehingga menjadikan penelitian ini pertama di Indonesia.

\section{KESIMPULAN}

Berdasarkan penelitian yang sudah dilakukan, didapatkan hasil bahwa hipotesis dalam penelitian ini diterima yakni kepemimpinan transformasional berpengaruh positif terhadap efikasi kolektif karyawan yang bekerja WFH. Semakin tinggi penilaian kepemimpinan transformasional dalam sebuah kelompok maka efikasi kolektif kelompok juga akan semakin tinggi. Selain itu, kepemimpinan transformasional berpengaruh terhadap efikasi kolektif sebesar $12,3 \%$ dan setiap penambahan $1 \%$ nilai gaya kepemimpinan transformasional maka nilai efikasi kolektif bertambah sebesar 0,303 .

Implikasi dalam penelitian ini adalah untuk para pengikut agar dapat mempertahankan ataupun meningkatkan rasa keyakinan dan kepercayaan yang ada antar sesama rekan kerja 
sehingga dapat mewujudkan kinerja yang optimal dan dapat mencapai tujuan bersama dalam bekerja, hal ini dapat dicapai dengan adanya dorongan yang diberikan oleh seorang pemimpin, dimana semakin kuat pemberian motivasi dan dorongan kepada para karyawan yang bekerja maka akan semakin meningkatkan keyakinan yang ada dalam kelompok kerja tersebut untuk menyelesaikan tugas-tugas yang ada sehingga dapat mencapai tujuan kelompok bersama. Selain itu, penelitian ini juga diharapkan dapat menjadi sumber informasi dan menambah kajian teoritis terkhusus untuk psikologi dalam bidang industri dan organisasi. Bagi peneliti selanjutnya diharapkan dapat menambah faktor-faktor lain yang dapat mempengaruhi efikasi kolektif, serta variabel-variabel lain yang dapat meningkatkan efikasi kolektif para karyawan seperti komitmen organisasi, kinerja karyawan, dan dukungan sosial.

\section{DAFTAR PUSTAKA}

Ahmad, F., Abbas, T., Latif, S., Rasheed, A. (2014). Impact of transformational leadership on employee motivation in telecommunication sector. Journal of Management Policies and Practices, 2(2), 11-25.

Anisah, C., \& Wisesa, A. (2021). The impact of covid-19 towards employee motivation and demotivation influence employee performance: a study of sayurmoms. Eqien - jurnal ekonomi dan bisnis, 8(2). 371-380. https://doi.org/10.34308/eqien.v8i2.254

Asbari, M., Novitasari, D., \& Goestjahjanti, F.S. (2020). Mempertahankan kinerja karyawan di masa pandemi covid-19: studi kasus pada industri ritel. JMK (Jurnal Manajemen dan Kewirausahaan), 5(3), 183-2013.

Azizah, F.A.U. (2017). Hubungan efikasi kolektif dengan kinerja karyawan dinas pendidikan. Skripsi. Fakultas Psikologi Universitas Muhammadiyah Malang.

Bandura, A. (1997). Self efficacy : the exercise of control. W.H. Freeman and Company : New York

Bass, B.M. (1999). Two decades of research and development in transformational leadership. European Journal of Work and Oragnizational Psychology, 8(1), 9-32.

Bass, B.M., Riggio, R.E. (2006). Transformational Leadership (2nd ed). Lawrence Erlbaum Associates : Mahwah, New Jersey

Çalik, T., dkk. (2012). Examination of relationships between instructional leadership of school principals and self-efficacy of teachers and collective teacher efficacy. Educational Sciences: Theory \& Practice, 12(4), 1-7.

Çepikkurt, F., Uluöz, E. (2017). Predictive power of group cohesion and perceived motivational climate for collective efficacy perception in the football teams. Sp Soc Int J Ph Ed Sp, 17(1), 91-97

Demir, K. (2008). Transformational leadership and collective efficacy: the moderating roles of collaborative culture and teachers' self-efficacy. Egitim Arastirmalari - Eurasian Journal of Educational Research, 33, 93-112.

Dua, M.H.C., \& Mea, M. (2020). Pengaruh work from home terhadap work life balance pekerja perempuan di kota Ende. Jurnal Ilmiah Manajemen Bisnis Dan Inovasi Universitas Sam Ratulangi, 7(2), 247-258.

Gita, R., Yuniawan, A. (2016). Pengaruh gaya kepemimpinan transformasional, motivasi kerja, dan budaya organisasi terhadap kinerja karyawan. Diponegoro Journal Of Management, $5(3), 1-12$.

Hemsworth, D., Muterera, J., \& Baregheh, A. (2013). Examining Bass's transformational leadership in public sector executives: A psychometric properties review. The Journal of Applied Business Research, 29(3), 853-862.

Jowett, S., Shanmugam, V., \& Caccoulis, S. (2012). Collective efficacy as a mediator of the 
association between interpersonal relationships and athlete satisfaction in team sports. International Journal of Sport and Exercise Psychology, 10(1), 66-78.

Joe, S.-W., \& Lin, C.-P. (2008). Learning online community citizenship behavior: A sociocognitive model. CyberPsychology \& Behavior, 11(3), 367-370

Jung, D.I., Sosik, J.J. (2002). Transformational leadership in work groups the role of empowerment, cohesiveness, and collective-efficacy on perceived group performance. Small Group Research, 33(3), 313-336.

Lippe, T.V.D., \& Lippényi, Z. (2019). Co-workers working from home and individual and team performance. Brian Towers (BRITOW) and John Wiley \& Sons Ltd, 1-2-, ISSN 1468-005.

Martínez, J.R., Guillén, F., \& Feltz, D. (2011). Psychometric properties of the spanish version of the collective efficacy questionnare for sports. Psicothema, 23(3), 503-509.

Mustajab, D., dkk (2020). Working from home phenomeno as an effort to prevent Covid-19 attacks and its impacts on working productivity. The International Journal Of Applied Business, 4(1), 13-21.

Pratama, A.D. (2018). Hubungan gaya kepemimpinan transformasional dengan group efficacy. Skripsi. Fakultas Psikologi Universitas Muhammadiyah Malang.

Setyawan, F.W.B., \& Lestari, R. (2020). Challenges of stay-at-home policy implementation during the coronavirus (Covid-19) pandemic in Indonesia. Jurnal Administrasi Kesehatan Indonesia, 8(1), 15-20

Smith, B. N., Montagno, R. V., \& Kuzmenko, T. N. (2004). Transformational and servant leadership: content and contextual comparisons. Journal of Leadership and Organizational Studies, 10 (4), 80-91.

Tucunan, R.J.A., Supartha, W.G., \& Riana, I.G. (2014). Pengaruh kepemimpinan transformasional terhadap motivasi dan kinerja karyawan (studi kasus pada PT. Pandawa). E-Jurnal Ekonomi dan Bisnis Universitas Udayana, 3(9), 535-550.

Wahyu, E.E., Widodo, T.W., Kurniawan, C.N. (2020). Urgensi kepemimpinan transformasional dan kecerdasan emosional pada perusahaan dalam merespons pandemi covid-19. Seminar Nasional Gabungan Bidang Sosial, Politeknik Negeri Malang.

Yuwono, Teguh., dkk. (2020). Analisis pengaruh efektivitas kepemimpinan transformasional dan kesiapan untuk berubah terhadap kinerja karyawan wanita di masa pandemi Covid-19. Jurnal Ilmiah Mahasiswa Ekonomi Manajemen, 5(3), 615-632.

Zhang, A. Y., Tsui, A. S., \& Wang, D. X. (2011). Leadership behaviors and group creativity in Chinese organizations: The role of group processes. Leadership Quarterly, 22, 851-862. 